\title{
NURSES 'KNOWLEDGE AND PRACTICE REGARDING POST-OPERATIVE PAIN MANAGEMENT FOR ORTHOPEDIC PATIENTS
}

\section{Dr. Naglaa El sayed Mahedy; Dr. Mona Abd EL-Rahman Mohamed; Fatma Belal Mustafa}

Assistant Professor of Medical-Surgical Nursing Faculty of Nursing Ain shams University ; Assistant Professor of Medical-Surgical Nursing Faculty of Nursing Port- said University; B.Sc, Mansoura University.

\begin{abstract}
Background: Pain management is a vital component of post-operative nursing care. Orthopedic patients in particular experience severe pain following surgical intervention. It was essential to explore the knowledge and clinical practice of nurses in orthopedic wards. Aim of the study: This study aimed to assess nurse's knowledge and practice regarding post-operative pain management for orthopedic patients. Design: A descriptive research design. Setting: The study was carried out in orthopedic department in (General governmental Hospital and ElMabrra Health Insurance hospitals) in Port Said City/Egypt. Sample: A convenience sample of 50 nurses caring |for patients at orthopedic department, General governmental hospital $(\mathrm{N}=30)$, and El-Mabrra Health Insurance $(\mathrm{N}=20)$ in period of 6 months. Tools: -I) A Structured selfadministered questionnaire that covering demographic data, and nurses' knowledge related to post-operative pain management for orthopedic patients (Tool II) Nurses' observational checklists. Results: the results revealed that $60 \%$ of the studied nurses had unsatisfactory level of general knowledge, while $90 \%$ of them had unsatisfactory level of nurses' practice. Conclusion: There is lack of nurses' knowledge and practice regarding post-operative pain management for orthopedic patients. Recommendations: conducting educational and training programs to improve nurses' knowledge and practice regarding post-operative pain management for orthopedic patients.
\end{abstract}

Keywords: Nurses' knowledge, Nurses' practice, orthopedic patients, Post-operative pain management. 


\section{INTRODUCTION}

Pain is defined by the International Association for the Study of Pain (IASP) as an unpleasant sensory and emotional experience associated with actual or potential tissue damage, or described in terms of such damage (International association for the study of Pain [IASP], 2012).

Pain is a subjective response, not always measureable or observable, to both physical and psychological stressors which all people experience at some point during their lives. Although pain is usually experienced as uncomfortable and unwelcome, it also serves a protective role, and may warn of potential health-threatening conditions. For this reason, pain needs to be assessed and considered an essential vital sign (Tylor\& Stanbury, 2014). Each individual pain event is a distinct personal experience. It is influenced by physiological, cognitive, psychological, sociocultural and spiritual factors. Pain is the symptom most associated with describing oneself as ill, and it is the most common reason for seeking healthcare (Eid, Manias, Bucknall, and Almazrooa , 2014).

A high level of pain is expected immediately after surgery. It has been reported that these are inadequate pain management practice after surgery particularly orthopedic surgery. Inadequate pain management is deleterious and can lead to number of post-operative complication. Therefore, it must be relieved completely (Jones et al., 2015). Pain is an individual and Subjective experience modulated by physiological, psychological and environmental factors such as previous events, culture, prognosis, coping strategies, fear and anxiety (parker ,2012).Effective management of pain in post-operative orthopedic patients, strong clinical knowledge, clinical practice in assessment of pain are essential for surgical nurses. The nurses must also perform well control of and effective administration of pain medication (Kawakita\& Okada, 2014).

Effective post-operative pain management has numerous benefits. This not only reduces the post-operative orthopedic patients pain but also leads to faster post operative recovery, improved sleep, increased mobility and leads to shorter hospital stay. However, several obstacles to this have been identified. These include knowledge deficit on use of appropriate pain measure, lack of time, lack of continuous education on assessment tool, shortage of nursing staff and lack of resources for adequate pain management (Eid et al., 2014).

Patients post orthopedic surgeries usually have musculoskeletal dysfunctions, such as unstable fractures, deformities, joint disorders, infected or necrotic tissues, traumas or tumors. The most frequent surgical procedures include open reduction with internal fixation and closed reduction with external fixation in fractures, arthroplasty and joint replacement. The goals of surgical procedures are as follows: to improve patients' body functions (Cheever, 2014). 
Effective pain management is crucial in the post-operative recovery of orthopedic patients, it was essential to explore the knowledge and clinical practice of nurses in orthopedic wards. Orthopedic surgery can be painful. Pain can affect the ability of the patient to perform normal activities of daily living, causing the patient to rely on others for care. Activity restrictions related to pain reduce quality of life in some patients, affecting the family unit and placing unnecessary stress on all those involved. Therefore, effective pain management is essential to promote early mobilization and prevent complications ( Al Qadire, \&Al Khalaileh,2014).

\section{Significance of the Study:}

Despite advances in technology and medications, unrelieved postoperative pain continues to be problematic for surgical patients. Statistics indicate that about 43 million patients in the United States experience acute postoperative pain, with pain intensities of moderate to severe which reported by $80 \%$ of these patients. Additionally, about $50 \%$ of postoperative orthopedic patients report unrelieved pain (Centers for Disease Control and Prevention Guidelines (CDC), 2013).

The assessment and management of acute postoperative pain is important in the care of postoperative orthopedic surgical patients. Management of postoperative pain relievers suffering and leads to earlier mobilization, shortened hospital stay, reduced hospital costs, and increased patient satisfaction (Paice, 2014).

The purpose of the study is to assess nursing knowledge and practice which may aids to improve successful pain management methods a and nursing role in the care of post operative orthopedic surgery .Improper pain management affects the patient's physiological state and also affects the patient's psychological well-being. Rates of surgical pathology in developed world are difficult to quantify. Post-operative pain in developing countries showed two-thirds of patients complained of moderate to unbearable pain 24hours postoperatively(O'Brien, 2014).

\section{AIM OF STUDY:}

Assess nurses' knowledge and practice regarding post-operative pain management for orthopedic patients.

\section{SUBJECT AND METHODS:}

\section{Research Design:}

A descriptive research design was used in this study.

\section{Study Setting:}


The study was conducted at orthopedic department in the following hospital in Port Said City:1- port-said General governmental Hospital in Port Said City/Egypt.

2- El-Mobrra Health Insurance hospital in Port Said City/Egypt.

\section{Study Subjects:}

A convenient sample of 50 nurses who provide direct post operative pain management for orthopedic patients during the first 24 hours for six months..

\section{Tools for data collection}

Data were collected via two tools which included nurses' self-administrated knowledge questionnaire and Nurses' practice Observational Checklist.

\section{Tool I: Nurses' self-administrated questionnaire: (Appendix 1)}

This questionnaire was developed by researcher based on the related literature (Abed El-

Rahman et al.,2013;Cohean, 2012;\&McCaffery,2011). It was written in Arabic language to avoid misunderstand. It was be composed of three parts:

\section{Part 1}

This part include items related to nurses' demographic data as( age, marital status, level of education, years of experience, source of knowledge about pain and its treatment, place of work and attendance of any training programs or courses in pain and its management).

\section{Part 2:}

It was developed by the researcher to assess the nurse's level of knowledge in relation to post-operative pain management of orthopedic patients. It was composed of 30 true and false questions related to nurses' general knowledge in relation to post-operative pain management of orthopedic patients including: definition, signs and symptoms, factors affecting pain, types of pain, assessment of pain, non-pharmacological management, pharmacological management of pain, and documentation.

\section{Scoring system of nurses' knowledge:}

The scores were distributed by giving "one" for correct answer and "zero" for incorrect one.

The total score of nurse's knowledge about post-operative pain management of orthopedic was 30 grades and it was considered that:

- $<75 \%$ of total grades was considered unsatisfactory level of nurse's knowledge about postoperative pain management of orthopedic patient $(<23$ grades $)$

- $\geq 75 \%$ of total grades was considered satisfactory level of nurse's knowledge about postoperative pain management of orthopedic patients ( $\geq 23$ grades). 


\section{Part 3:}

It was composed of ten (YES or NO) questions used to identify barriers of nurses' pain assessment and management.The response of yes was given (one) score, while the response of no was given (zero) score.

\section{(II): Nurses' practice Observational Checklist :( Appendix II)}

It was developed by the researcher based on related literatures (cohean, 2012) to assess nurses' practical skills regarding post-operative pain management of patients after orthopedic surgery.

\section{It composed of two parts:}

\section{The first part:}

It composed of five steps used to assess nurses' practice regarding pain assessment.

The second part:

\section{It composed of two sections:}

\section{The First section}

It composed of seven items to assess nurses' practice regarding non pharmacological pain management and included (Nurse patient relationship, cold and heat compresses , positioning, guided imagery, distraction, massage, breathing exercise) it included 37 steps and distributed as the following:

-Nurse patient relationship (5steps).

- Cold and heat compresses (10 steps).

-Positioning (4 steps).

-Guided imagery (6 steps).

-Distraction (4 steps).

-Massage (4 steps).

-Breathing exercise (4 steps).

\section{Second section:}

It was developed by researcher included 21 steps used to assess nurses' practical skills for administration of analgesic drug during intra muscular administration, as it is the only method used to administer analgesic in study setting.

\section{Scoring system}

Regarding the total scores for two sections of the nurses' practice about post-operative pain management for orthopedic patients, nurses' practices were compared with a model key answer, where (one) scores was given for steps done, (zero) for not done or for steps done incorrectly. And total grades was 58 scores Nurses' practice has been classified as follows; satisfactory practice for nurses who got scores $\geq 75 \%$ ( $\geq 44$ grades), while unsatisfactory practice 
for nurses who got scores $<75 \%$ ( $<44$ grades). The total score was calculated by summing up and converted into a percent score.

\section{OPERATIONAL DESIGN}

The operational design includes preparatory phase, reliability, content validity, pilot study and field work.

\section{A-The Preparatory Phase:}

It included reviewing of literature, different studies and theoretical knowledge of various aspects of the problems using books, research articles, internet, periodicals and magazines to develop tools for data collection.

\section{B-Content validity :Appendix III}

The tool was tested for its content validity, comprehensiveness and applicability by 11 experts of professors and lectures from the medical-surgical nursing department; Faculty of Nursing, Port Said University and El Mansoura University and from medicine department, Faculty of Medicne,Al-Azher University who revised the tools and modifications were done according to their opinion.

\section{C-Reliability:}

The Cronbach alpha coefficient was used to assess the consistency of the study tool.

1. In relation to nurses' questionnaire regarding post-operative pain management for orthopedic patients with Cronbach's Alpha was .70 (No of items 40).it was valid and reliable questionnaire with psychometric properties.

2. In relation to nurses' practices regarding post-operative pain management for orthopedic patients with Cronbach's Alpha was .75 (No of items (58).

3. Total Reliability for both the questionnaire to assess nurses' knowledge and the checklist to assess nurses' practices regarding post-operative pain management for orthopedic patients, Cronbach's Alpha correlation coefficent was 0.70 (No of items 98).

\section{D -pilot study:}

After review of the questionnaire by experts and their approval, a pilot study was carried out before starting the actual data collection. The purpose of the pilot study was to ascertain the clarity, and applicability of the study tools, and to identify the obstacles and problems that may be encountered during data collection. It also helped to estimate the time needed to fill in the questionnaire. Based on the results of the pilot study, modifications, rephrasing, omissions, and rearrangement of some questions were done. It was done on five nurses from port -Said Hospitals, and they were not included in the total sample of the research work to ensure accuracy of results. 


\section{E- Field work description:}

The actual field work was started during period from the beginning of January (2017) to the end of June (2017) for data collection. The researcher visited General governmental Hospital and ElMabrra Health Insurance hospital in Port Said City, three days weekly at morning and afternoon shifts to collect the data by using the previous tools. The purpose of the study was explained by the researcher to nurses who agreed to participate in the study. The first phase that was done by the researcher through observation of the studied nurses when they did their actual work. At first, the researcher was observing nurses' practical skills about pain assessment and management. The time needed to complete the checklist varies ranged between 20-30 minutes. All nurse was observed for 30 hours at beginning of each shift for morning shift then she was asked to fill in the knowledge assessment questionnaire. Which took about 15 to 25 minutes from each nurse. Distribution of the questionnaire sheet was done after the end of morning shift for nurses working at morning shift and was given to the afternoon (evening shift) nurses before starting their work.

\section{Ethical Considerations:}

The agreement for participation of the subjects was taken after aims of the study have been explained to them. A verbal informed consent was obtained from the nurse to ensure willingness to engage in the study after explaining its purpose. They were informed about their rights to refuse or withdraw at any time with no consequences on their care. The study interventions could not have any harmful effect on participants and they were assured that the information collected would be treated confidentially and used for the research purpose only.

\section{ADMINISTRATIVE DESIGN}

A formal letter from the Dean of the Faculty of nursing, Port Said University was submitted to General governmental Hospital and El-Mobrra Health Insurance hospital in Port Said City. The aim of the study and procedures were explained to them to attain their cooperation. An official permission for data collection was obtained from directors of General governmental Hospital and El-Mabrra Health Insurance hospital in Port Said City.

\section{STATISTICAL DESIGN}

Data entry and analysis were done using SPSS 17 (statistical packages for social science). Quality control was done at the stages of coding and data entry. Data were presented using descriptive statistics in the form of frequencies and percentages for qualitative variables, and means and standard deviations for quantitative variables as well as inferential statistics. Qualitative variables were compared using $\mathrm{f}$ test, $\mathrm{t}$ test $\& \mathrm{r}$ test. Person correlation test were used to test the relation between the studies variables. For interpretation of results, the $p$ value $\leq 0.05$ 
was considered significant level in some tables. Meanwhile, the $p$ value $\leq 0.001$ was considered highly significant level for other table.

\section{RESULTS:}

Table (1): Showed distribution of the studied nurses according to their demographic characteristics. This table results, showed that, 44\% of studies nurse's ages between (20-30) years with mean $\pm \mathrm{SD}=29.04 \pm 7.20$. About educational level, $54 \%$ of studied nurses had diploma of technical secondary school of nursing. All of them (100\%) were female. Moreover, $42 \%$ of studied nurses worked at El- Mabarra hospital and $58 \%$ of them worked at General hospital and $76 \%$ of studied nurses were married.

Figure( 1) showed years of experience of studied nurses, $62 \%$ of them had more than ten years of experience and $14 \%$ of them had experience from five to ten years.

Table 2 illustrated nurses' basic knowledge about pain, 90\% of studied nurses had correct knowledge regarding that the real pain had obvious cause. And $52 \%$ had correct knowledge that the pain is fifth vital signs, $88 \%$ of studied nurses had correct knowledge about signs and symptoms of pain (physiological changes and vital signs changes). $84 \%$ of studied nurses had correct knowledge about factors affecting pain (age ,gender and anxious). 100\% of them had correct knowledge about types of pain.98\% of studied nurses had correct knowledge about assessment of pain after orthopedic surgery. Also, $88 \%$ of them had correct knowledge about pain scale.

Table (3): illustrated that $80 \%$ of the studied nurses had correct knowledge about benefits use of relaxation technique, $98 \%$ of nurses had correct knowledge regarding relaxation as a role of nurse , 90\% of studied nurses had correct knowledge about distraction efficacy and medications of pain management, and methods of analgesic medication, and all of them $100 \%$ had correct knowledge that Paracetamol and diclofinac is analgesic medications and98\%of them had correct knowledge about administrating sterile saline. While, 92\%of studied nurses had incorrect knowledge about heat compresses on affected part and intra venous methods as the common methods for giving analgesic medication.

Figure (2): represented that, $60 \%$ of studied nurses had unsatisfactory level of knowledge about assessment and management of orthopedic pain, while $40 \%$ of them had satisfactory level of knowledge.

Table (4): showed that ,94\% of studied nurses had satisfactory level of practice regarding assessment of pain post-operative for each patient and before changing position ,68\%of them use appropriate pain assessment tool, $88 \%$ of them assess pain before invasive procedure, $98 \%$ 
of them satisfactory record location of pain and $92 \%$ of them had satisfactory practice regarding assessment and recording frequency, duration, alleviating and aggravating factors.

Figure (3): revealed that $88 \%$ of studied nurses have satisfactory practice for total pain assessment, while $12 \%$ of them have unsatisfactory practice for total pain assessment

Figure (4): revealed that the studied nurses $96 \%, 96 \%$ and $98 \%$ had satisfactory practice regarding establish trust relationship, positioning and breathing exercise respectively. While $92 \%, 94 \%, 100 \%$ and $92 \%$ of them had unsatisfactory practice regarding heat\&cold compresses, guided imagery, distraction and massage respectively.

Figure (5): represented that 98\%ofthe studied nurses had unsatisfactory level of practice regarding total non-pharmacological pain management, while $2 \%$ had satisfactory level.

Figure (6): showed that $54 \%$ of studied nurses had satisfactory practice of pharmacological management, while $46 \%$ of them had unsatisfactory practice

Figure (7): shows that $90 \%$ of the studied nurses had unsatisfactory level of practice regarding total pain management, while $10 \%$ of them have satisfactory practice.

Table (5): revealed that, there was statistically significant positive weak correlation between total nurse's knowledge and their age $(\mathrm{p}=.020)$, and no statistically significant correlation between total knowledge and years of experience $\mathrm{p}=(.139)$, while there was no statistically significant correlation between total nurse's practice and both of age ,and years of experience. Table (6): showed that, there was highly statistically significant relation between total nurse's knowledge and education $(\mathrm{p}=.000)$ while, there was no relation between total practice and education.

Table (7): showed that, there was no statistically significant correlation between total nurse's knowledge and total nurse's practice $(\mathrm{p}>.005)$ 
Table 1: Frequency and percentage distribution of the studied nurses according to their demographic data $(\mathrm{n}=50)$

\begin{tabular}{|c|c|c|}
\hline Item & $\begin{array}{l}\text { Frequency } \\
\text { (n) }\end{array}$ & $\begin{array}{c}\text { Percent } \\
(\%)\end{array}$ \\
\hline \multirow[t]{2}{*}{$\begin{array}{l}\text { Age/ years: } \\
\text { Less than } 20 \\
20 \text { to less than } 30 \\
30 \text { to less than } 40 \\
\geq \text { than } 40 \\
\text { Mean } \pm \text { SD }\end{array}$} & $\begin{array}{c}6 \\
22 \\
20 \\
2\end{array}$ & $\begin{array}{c}12 \\
44 \\
40 \\
4\end{array}$ \\
\hline & \multicolumn{2}{|c|}{$=29.04 \pm 7.20$} \\
\hline $\begin{array}{l}\text { Education: } \\
\text { Diplome } \\
\text { Technical institute } \\
\text { B.Sc. of nursing } \\
\text { Post graduate }\end{array}$ & $\begin{array}{l}27 \\
13 \\
8 \\
2\end{array}$ & $\begin{array}{l}54 \\
26 \\
16 \\
4.0\end{array}$ \\
\hline $\begin{array}{l}\text { Gender: } \\
\text { Female } \\
\text { Male }\end{array}$ & $\begin{array}{c}50 \\
0\end{array}$ & $\begin{array}{c}100 \\
0.0\end{array}$ \\
\hline $\begin{array}{l}\text { Place of occupation: } \\
\text { El- Mabarra hospital } \\
\text { General hospital }\end{array}$ & $\begin{array}{l}21 \\
29 \\
\end{array}$ & $\begin{array}{l}42 \\
\mathbf{5 8}\end{array}$ \\
\hline $\begin{array}{l}\text { Marital status } \\
\text { Single } \\
\text { Married }\end{array}$ & $\begin{array}{l}12 \\
38\end{array}$ & $\begin{array}{l}24 \\
76\end{array}$ \\
\hline
\end{tabular}

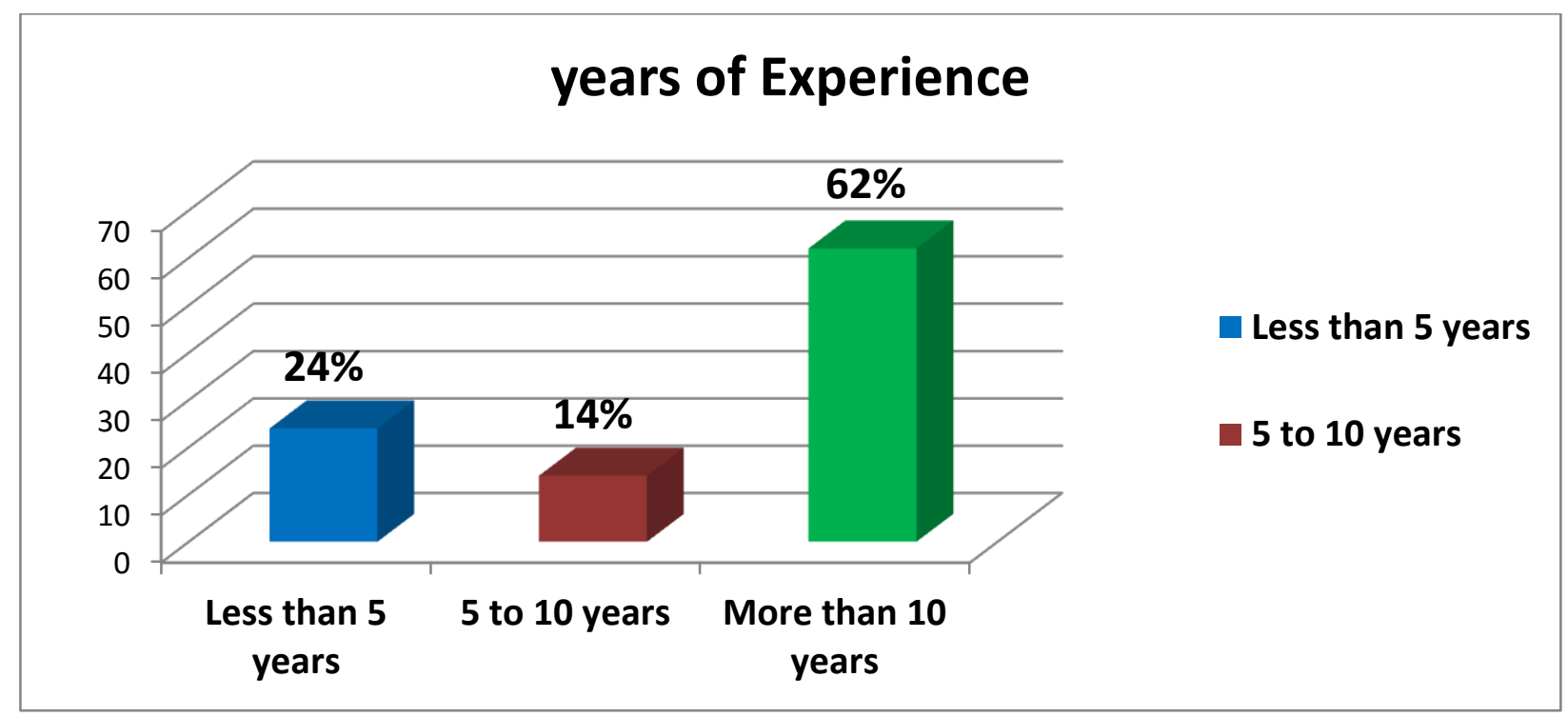

Figure 1: percentage distribution of the studied nurses according to their years of experience $(n=50)$ : 
Table (2): Distribution of the studied nurses according to their correct knowledge about assessment of pain $(n=50)$

\begin{tabular}{|l|c|c|c|c|}
\hline \multicolumn{1}{|c|}{ Item } & \multicolumn{2}{c|}{ Correct } & \multicolumn{2}{c|}{ incorrect } \\
\cline { 2 - 5 } & $\mathbf{N}$ & $\mathbf{\%}$ & $\mathbf{N}$ & $\mathbf{\%}$ \\
\hline 1. The real pain is only one which has clear and obvious cause. & 45 & 90 & 5 & 10 \\
\hline 2. The pain considered the fifth vital signs. & 26 & 52 & 24 & 48 \\
\hline $\begin{array}{l}\text { 3. Physiological changes associated with pain confirm patient's } \\
\text { statement of pain }\end{array}$ & 44 & 88 & 6 & 12 \\
\hline 4. Remarkable changes in vital signs are real pain. & 42 & 84 & 8 & 16 \\
\hline 5. Patient awareness affect his feeling with pain & 40 & 80 & 10 & 20 \\
\hline 6. Factors affecting pain tolerance. & 42 & 84 & 8 & 16 \\
\hline 7. Anxiety plays essential role in patient recognizing in pain & 48 & 96 & 2 & 4.0 \\
\hline 8. Acute pain. & 50 & 100 & 0 & 0.0 \\
\hline 9. Duration of chronic pain. & 50 & 100 & 0 & 0.0 \\
\hline 10. Orthopedic operations pain differs from other operation pain. & 36 & 72 & 14 & 28 \\
\hline $\begin{array}{l}\text { 11. The continued assessment for pain after orthopedic surgery is } \\
\text { essential. }\end{array}$ & 49 & 98 & 1 & 2.0 \\
\hline 12. The nurses determine severity of pain not the patient. & 12 & 24 & 38 & 76 \\
\hline 13. Using the pain scale for assessment of the pain & 44 & 88 & 6 & 12 \\
\hline
\end{tabular}

Table (3) :Distribution of studied nurses according to their correct knowledge about management of pain $(n=50)$ :

\begin{tabular}{|c|c|c|c|c|}
\hline \multirow[t]{2}{*}{ Item } & \multicolumn{2}{|c|}{ Correct } & \multicolumn{2}{|c|}{ Incorrect } \\
\hline & $\mathbf{n}$ & $\%$ & $\mathbf{N}$ & $\%$ \\
\hline $\begin{array}{l}\text { 1- The nurse uses non pharmacological methods first for } \\
\text { pain management. }\end{array}$ & 29 & 58 & 21 & 42 \\
\hline $\begin{array}{l}\text { 2- When use non pharmacological methods are effective helps } \\
\text { in relieving pain after orthopedic surgery. }\end{array}$ & 29 & 58 & 21 & 42 \\
\hline 3- Benefits use of relaxation technique after orthopedic Surgery & 40 & 80 & 10 & 20 \\
\hline 4- $\quad$ Relaxation as role of nurse for relieving pain relax patient. & 49 & 98 & 1 & 2.0 \\
\hline 5- When use heat compress on affected part. & 4 & 8.0 & 46 & 92 \\
\hline 6- When distraction is not efficient & 45 & 90 & 5 & 10 \\
\hline 7- Medication for pain management after surgery. & 45 & 90 & 5 & 10 \\
\hline 8- Administrating sterile saline by linjection. & 49 & 98 & 1 & 2.0 \\
\hline $\begin{array}{l}\text { 9- Intravenous methods are the common methods for giving } \\
\text { analgesic medication. }\end{array}$ & 4 & 8.0 & 46 & 92 \\
\hline 10- Paracetamol and diclofinac is analgesic. & 50 & 100 & 0 & 0.0 \\
\hline
\end{tabular}




\section{Total Knowledge}

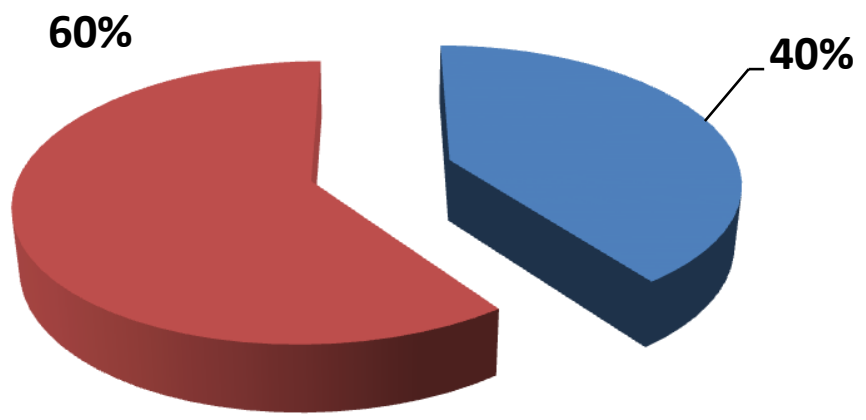

Satisfactory

Unsatisfactory

Figure (2): Distribution of the studied nurses according to their total knowledge about assessment and management of pain $(\mathrm{n}=50)$

Table (4): Distribution of the studied nurses according to their practice regarding pain assessment $:(n=50)$

\begin{tabular}{|c|c|c|c|c|c|}
\hline \multirow{2}{*}{\multicolumn{2}{|c|}{ Item }} & \multicolumn{2}{|c|}{ Satisfactory } & \multicolumn{2}{|c|}{ Unsatisfactory } \\
\hline & & $\mathbf{n}$ & $\%$ & $\mathbf{N}$ & $\%$ \\
\hline & ss pain for each patient post-operative. & 47 & 94 & 3 & 6 \\
\hline & appropriate pain assessment tool. & 34 & 68 & 16 & 32 \\
\hline & ss pain before invasive procedure. & 44 & 88 & 6 & 12 \\
\hline & ss pain before changing position & 47 & 94 & 3 & 6 \\
\hline & $\begin{array}{l}\text { ss and record pain and its } \\
\text { cteristics: }\end{array}$ & & & & \\
\hline & Location & 49 & 98 & 1 & 2 \\
\hline & Quality & 43 & 86 & 7 & 14 \\
\hline c. & Frequency & 46 & 92 & 4 & 8 \\
\hline & Duration & 46 & 92 & 4 & 8 \\
\hline & Alleviating factors & 46 & 92 & 4 & 8 \\
\hline & Aggravating factors & 46 & 92 & 4 & 8 \\
\hline
\end{tabular}




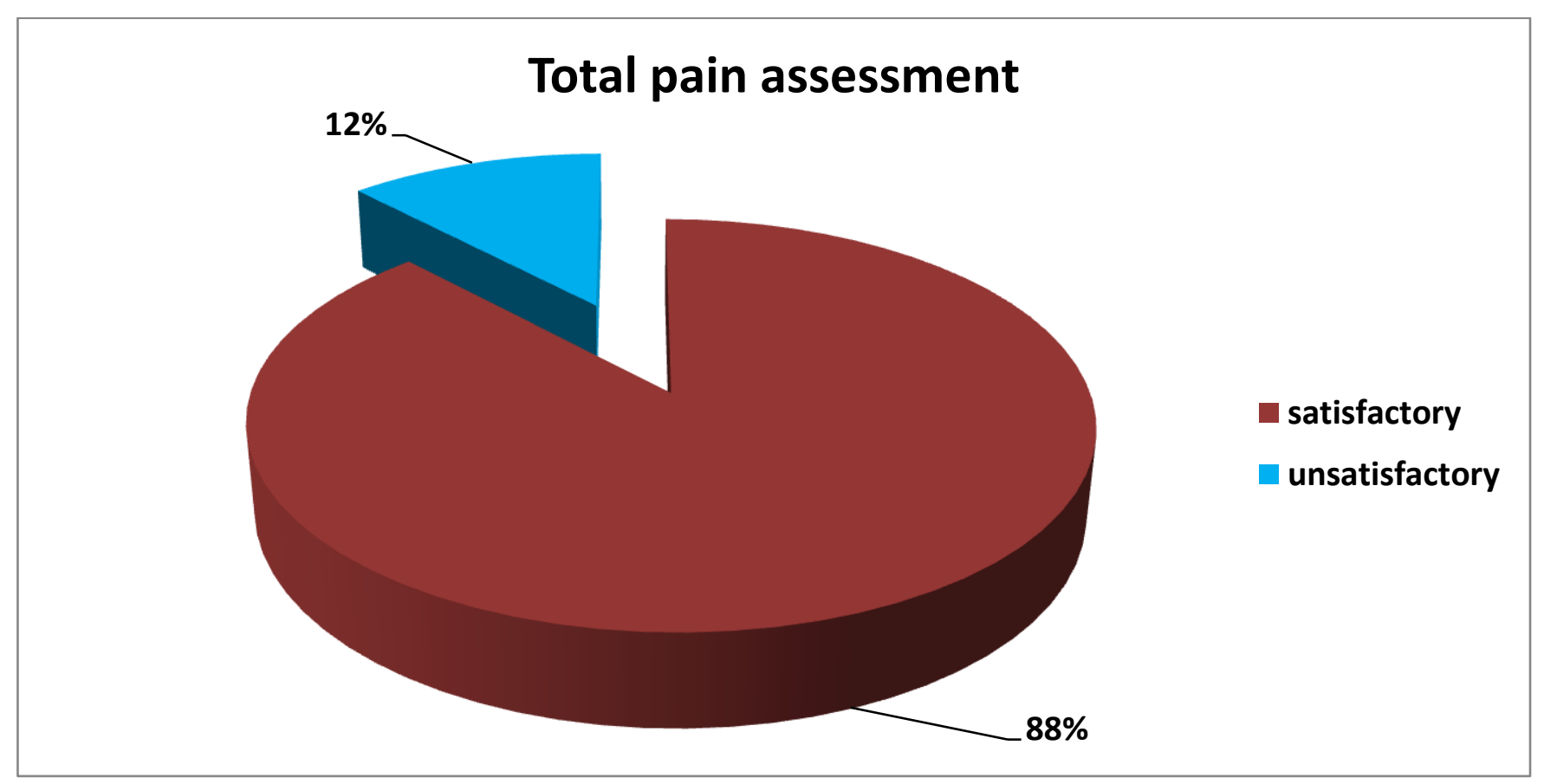

Figure (3): Distribution of the studied nurses according to their practice regarding total pain assessment $(\mathrm{n}=50)$ : 


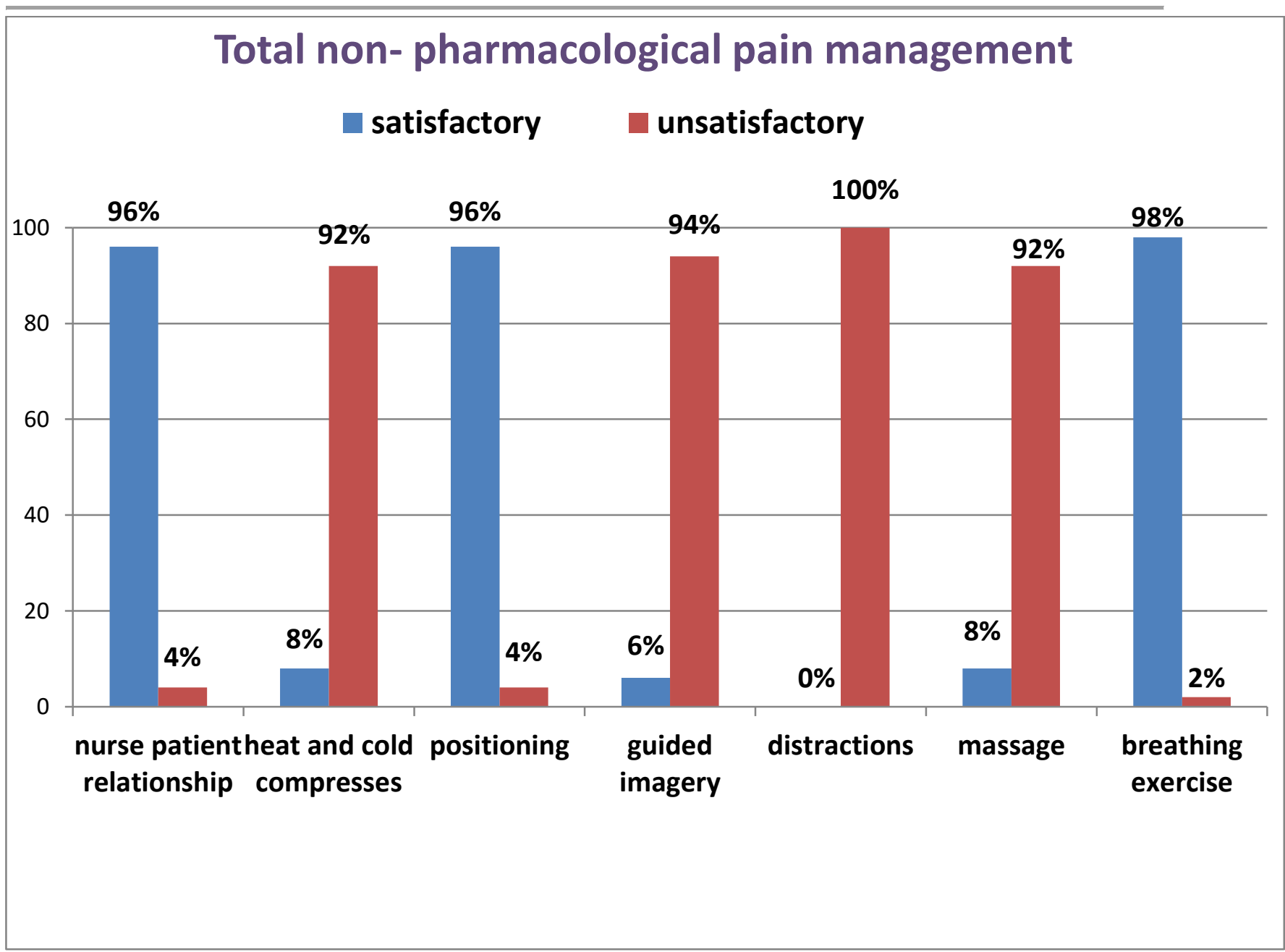

Figure (4): Distribution of the studied nurses according to their practice of total nonpharmacological routes of pain management $:(n=50)$

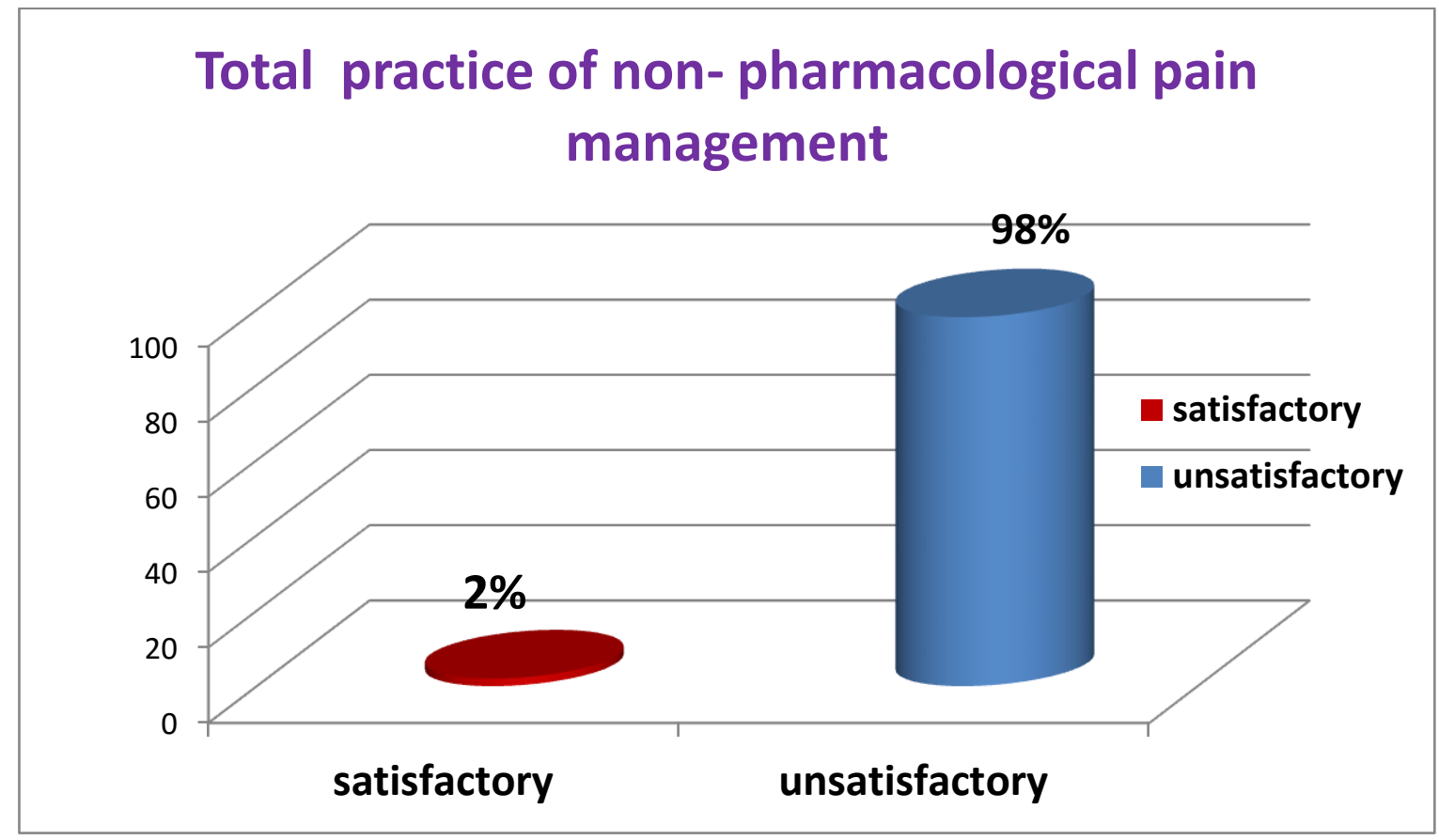

Figure (5): Distribution of the studied according to their total practice of non-pharmacological pain management $:(n=50)$ 




Figure (6): distribution of the studied nurses according to their total practice of

Pharmacological management :(n=50)

$X^{2}$ :



Figure (7): distribution of the studied nurses according to their total Pharmacological management: 
Table (5): Correlations of the studied nurses' age and years of experience with both total knowledge and total practice:

\begin{tabular}{|l|c|c|c|c|}
\hline \multirow{2}{*}{\multicolumn{2}{|c|}{ Item }} & \multicolumn{2}{|c|}{ Total knowledge } & \multicolumn{2}{c|}{ Total practice } \\
\cline { 2 - 5 } & $\mathbf{r}$ & $\mathrm{p}$ - value & $\mathbf{r}$ & p- value \\
\hline Age & $.328^{*}$ & .020 & .092 & .525 \\
\hline Years of experience & & & & \\
& .212 & .139 & .244 & .087 \\
\hline
\end{tabular}

*Weak positive correlation

N.B
0.0 No correlation
0.3 Weak correlations
0.5 Moderate correlation
0.7 Strong correlation
1 perfect correlation

Table (6) Relations between education and total knowledge and total practice:

\begin{tabular}{|c|c|c|c|c|}
\hline \multirow{2}{*}{ Item } & \multicolumn{2}{|c|}{ Total knowledge } & \multicolumn{2}{c|}{ Total practice } \\
\cline { 2 - 5 } & $\mathbf{f}$ & p- value & f & p- value \\
\hline Education & & & & .311 \\
\hline
\end{tabular}

Table (7): Correlations between the studied nurse's total knowledge and total practice:

\begin{tabular}{|c|c|c|}
\hline \multirow{2}{*}{ Item } & \multicolumn{2}{|c|}{ Total knowledge } \\
\cline { 2 - 3 } & $\mathbf{r}$ & p- value \\
\hline Total practice & -.136 & .346 \\
\hline
\end{tabular}

N.B

$\mathbf{P} \leq \mathbf{0 . 0 0 1}$ highly significant

$\mathbf{P}>\mathbf{0 . 0 0 5}$ non significant 


\section{DISCUSSION:}

Pain is one of the most common experiences and stressors in orthopedic patients and also pain is one of the most common problem faced nurses working with orthopedic patients. The role of the nurse in pain management is to perform pain assessment, identify goals for pain management, provide patient teaching, perform physical care, help relieve pain by administering pain-relieving interventions (including both pharmacologic and nonpharmacologic approaches), assess the effectiveness of those interventions, monitor for adverse effects, and serve as an advocate for the patient when the prescribed intervention is ineffective in relieving pain (Brown et al., 2014).

The nurses have a responsibility to understand the experience of patient's pain and help orthopedic patients to recovery in post-operative. Most of orthopedic surgery require special device as traction, cast, internal fixation and patients assume special uncomfortable position to maintain joints function and also alter mobility, additionally orthopedic surgery is deep surgery which affected bones, nerves and tendons all of this factors could aggravated patients pain intensity and discomfort (Brennen, Carr \& Cousins, 2014).

\section{Part I: Demographic characteristics of the studied nurse's}

As regard educational level, the present study revealed that more than half of studied nurses were in diploma degree five years and near to two third of them their experiences more than ten years, from researchers point of review this may be due to the diploma level of education and pain management were received short period during graduate about two hours lecture during graduated. This finding is in line with Nelligan \& Mac Cartney, (2015) who mentioned that the majority of nurses were in diploma degree and with an experience more than 10 years, This is in contrast with the result of Khatib et al.,(2017) who mentioned that the majority of the studied nurses had bachelors degree and the mean years of experience was low than 5 years.

In respect to receiving pervious training, the finding of this study also indicates that more than one third of studied nurses receive training courses in pain assessment and management, near to two third of them received it twice. From researchers, point of view this may be due to the importance continuous training program about orthopedic pain management is required to improve nursing management of orthopedic pain help patients recovering without complications this result is supported with Kituyi et al.,( 2011) who stated that about one third of nurses participating in their studies had undergone specialized training for assessment and 
management about pain. Also, in previous study by Reid et al., (2016) they found that only few nurses have attended a medical conference about pain management.

\section{Part (2): knowledge about assessment and management of pain}

The present study showed that two fifth of nurses had unsatisfactory level of knowledge regarding post-operative pain management .From researcher point of view it may be due to several factors as, lack of education and training program These findings are supported by many researchers Abd El-Rahman et al., 2013\&McCaffery, Ferrell's ,(2013) who found that nurses had inadequate knowledge about post-operative pain management . and in contrast with Clarke et al.,(2013) found that most of nurses had adequate knowledge about post-operative pain management due to many of studied nurses of his research had high level of education as master-prepared nurses and bachelor nurses had a mean score $10 \%$ higher than nurses prepared at diploma and associate nurses.

As regarded to correlation between total nurse's practice and total nurse's knowledge There was no a statistically significant correlation between total nurse's practice and total nurse's knowledge, no a statistically significant relation between total practice and their characteristics (age, years of experience and education). It might be related to lack of training programs. So, from the researcher view, the hospital should concern of providing continuous training for orthopedic nurses to gain and update their knowledge and practice as such, they are critical o provision of quality care post-operative.

This finding supported by Nelligan \& Mac Cartney(2015) stressed that training programs were required to target the specific needs of nursing staff. In the same line McCaffery, (2013) emphasized that educational programs should provide nurses with the necessary behavioral skills basic o efficient practice of the work.

As regarded to correlation between total nurse's knowledge and some characteristics(education and age )There was a statistically significant positive relation between total knowledge and some characteristic of the studied nurses as (education and age)his supported by Strassels et al.,(2016) that show there was positive relation between knowledge and education and age of the nurse and his result contradicted with Ally,(2013)that show there was no relation between age and knowledge.

The current study revealed that majority of studied nurses had satisfactory practice of change position to patient to relieve pain from the researcher point of view it may be due to easy to manage, and it available and cost effective, these results supported by d resources Fong \&Lui , 2015 who found that the majority of nurses had satisfactory and good practice using positioning to relieve pain. 
In current study revealed that majority of nurses had unsatisfactory of practice to their total non-pharmacological pain management. From the researcher point of view, it may be due to ignorance of its importance and methods of non-pharmacological methods. This result supported with Yurdanur, (2012) who found that the nurses had no experience to use non pharmacological methods to relieve orthopedic pain post-operative. There were several barriers affected it as nurse's heavy workload, lack of experiences in using non-pharmacological methods and lack of co-operation .beliefs and cultures of patients. That, in contrary of World health organization ,2012 ) that found the nurses were experienced and patients had experienced post-operative orthopedic pain use non pharmacological ,non pharmacological methods when used together with pharmacological were likely achieving the desired results that relieve orthopedic pain post-operative.

\section{Total pharmacological routes of pain management.}

The current study revealed that more than half of studied nurses had satisfactory practice to their total pharmacological management from the researcher point of view it may be due to compliance of nursing staff about its importance and pharmacological interventions for pain relief are the principle modalities for pain alleviation in the acute surgical, this results supported with many researchers who have also found that nurses illustrated the good practice in pharmacological aspects of pain and its management. Allerd et al.,(2011) reported that pharmacology is vital in the management of orthopedic pain. Pain relief after surgery is important for the well-being and comfort of patient because it contribute to faster and better recovery. Also, maintain patient's mobility and prevent joint deformity and loss its function.

The current study results finding that, there were no statistically significant relations between total knowledge and all years of experience of studied nurses it was found that, more than two third of nurses of experience more than 10 years had unsatisfactory level of knowledge. This result similar to Wang et al., (2015) mentioned that, there was insignificant difference between nurse's knowledge score and their years of experience group.

Meanwhile, the current study finding of result was in contrast with Meisner et al., 2015 illustrated that there were statistical significant improvements in total knowledge score for both study groups before and after educating them the safety protocol. Also, Tse MMY et al., (2011) stated that the findings of nurses' knowledge assessment reflect the effectiveness of education and training which has been claimed as a useful tool to improve the nurses' knowledge Total non-pharmacological routes of pain management. 
As regarded to correlation between total nurse's knowledge and total nurse's practice, the present study found that there was no statistically significant negative correlation between them. These results are in accordance with finding of Brown et al.,(2014) who found that there was no relation between knowledge and practice, lack of knowledge and skills among nursing staff in caring patients for patients after orthopedic surgery.

Meanwhile, this finding of result is not confirmed with Asti \& Buyukyilmaz, (2013) who found that there was positive relation between total nurse's knowledge and total nurse's practice, because good training for staff nursing, and developing specific procedure videos about caring patient after orthopedic surgery.

\section{CONCLUSION:}

The studied nurses had lack of knowledge and practice regarding management of postoperative orthopedic pain. However two third of studied nurses had unsatisfactory level of knowledge and most of them had unsatisfactory level of practice. Moreover, there is no statistically significant relation between total nurses' knowledge and total nurse's practice. Most of the studied nurses $(98 \%)$ of studied nurses had unsatisfactory total practice of nonpharmacological pain management, but (96\%) of them had satisfactory practice level regarding establish trust relationship, positioning and breathing exercise.

\section{RECOMMENDATIONS:}

- designing and implementing a continuous education program on pain and its assessment with special focus on methods of assessment, guidelines, how to use assessment tools, protocols and charts for proper documentation for post-operative orthopedic patients.

- Providing for a supportive environment which can be attained through improving staffing number, provision of support supervision by experienced and skilled nurses.

- Conducting training program about non pharmacological methods for management of orthopedic pain post-operative by training courses in pain assessment and management.

\section{REFERENCES:}

Abed EL-RahmanM.,Alkalaldeh M., and Muhbes F.,(2013): knowledge and attitude towards pain management. Comparison between oncology and non-oncology Vnurses in Jordan. International Journal of Advanced Nursing Studies. 2(2): 95-100. 
Alley L., (2013): The influence of an organizational pain management policy on nurses' pain management practices. Oncology Nursing Forum, 5(28):867-874.

Allred KD, Byers JF \& Sole ML (2010): the effect of music on postoperative pain and anxiety. Pain Management Nursing 11(1): 15-25.

Brennan, F., Carr, D.B., \& Cousins, M. (2015): Pain management: a fundamental human right. Anesthesia and Analgesia, 10(5):205-221. Retrieved on October 2016.

Brown T., Bowman M., and Eason R., (2014): Assessment of nurses' attitudes and knowledge regarding pain management. The Journal of Continuing Education in Nursing, 30(11): 132-139.

Clarke EB, French B, Bilodeau ML, Capasso VC, Edwards A, Empoliti J (2013): Pain management knowledge, attitudes and clinical practice: The impact of nurses' characteristics and education. Pain Symptom Manage; 11(4):18 -31.

Cohen MM, Rose DK,\& Yee DA: (2012) :Changing the practice of pain management, 6(5): 6-7.

Cousins, M., Brennan, F., \& Carr, D. (2014): Pain relief: a universal human right. Pain, 112(1-2), 1-4. Retrieved from on 28th August, 2011 from Hinari.

International association for the study of Pain [IASP] (2012): IASP Taxonomy: Pain Terms. Accessed 19 January 2017, retrieved from http://www.iasp-pain.org/Taxonomy

Khatib, S., Razvi, S., Kulkarni, S., \&Parab, S. (2017): A survey of the current acute postoperative pain management practices in tertiary care teaching hospitals in Maharashtra. Indian Journal of Anaesthesia, 61(3): 215-218.

Kituyi, W.P., Imbayo, K.K., Wambani, J.O., Sisenda, T.M., \&Kuremu, R.T. (2011): Postoperative pain management: Clinicians' knowledge and practices on assessment and measurement at Moi Teaching and Referral Hospital. East and Central African Journal of Surgery, 16 (12):111-113.

Education in Nursing, 42(6): 251-258.

Mac CartneyJ., and NelliganK. , (2015): Post-operative pain management after total knee arthroplasty in elderly patients. The Journal of Nursing Administration, 9(11):141-145. 
McCaffery M., and Ferrell R., (2013):Influence of professional vs.personal role on pain assessment and use of opioids. The Journal of Continuing Education in Nursing. 28(2): 69-77.

McCaffery, M. (2013): The debate over placebos in pain management.American Journal of Nursing, 106(2):62-65.

McDonald, D.D., McNulty, J., Erickson, K. \&Weiskopf, C. (2014): Communicating pain and pain management needs after surgery. Applied Nursing Research, 13(2):70-75.

Meissner, W., Coluzzi, F., Fletcher, D., Huygen, F., Morlion, B., Neugebauer, E., Montes, A., Pergolizzi, P., \&Pergolizzi, J. (2015): Improving the management of postoperative acute pain: priorities for change. Current Medical Research and Opinion,31(11): 2131-2143.

O'Brien S., Dalton J., Konsler, G., and Carlson J., (2014): The knowledge and attitudes of experienced oncology nurses regarding the management of cancer-related pain. Oncology Nursing Forum, 23(11):515-521.

Paice A., Toy C. , and ShottS. , (2014): Barriers to orthopedic pain relief: Fear oftolerance and addiction. Journal of Pain and Symptoms Management. 16(18); 1-9.

South African Nursing Council. (2013): Regulations relating to the scope of practice of persons who are registered or enrolled under the Nursing Act, 1987. Regulation R.2598, in terms of the Nursing Act, 2013 (Act 50, 1978 as amended). [Online].Available: http://www.sanc.co.za/publications.htm. [2014, December 3]

Reid, M., Ong, A.D., \& Henderson, R. (2016): When we need on-pharmacologic approaches to manage chronic low back pain in olderadults. JAMA Internal Medicine. http://www.ncbi.nlm.nih.gov/pmc/articles/PMC3996195

Strassels, S., Thirlby, R., Viscusi, E., Walco, G., Warner, L., Weisman, S., \& Wu, C.(2016): Management of Post-operative Pain: A Clinical Practice Guideline From the American Pain Society,22(5):199-203.

Tse MMY, Wan VTC \& Ho SSK (2011): Physical exercise: Does it help in relieving pain and increased mobility among older adults with chronic pain? Journal of Clinical Nursing, 20(10):635-644. 
Wang, T.J., Chang, C.F., Lou, M.F., Ao, M.K., Liu, C.C., Liang, S.Y., Wu, S.F., Tung, H.H.( 2015): Biofeedback relaxation for pain associated with continuous passive motion in Taiwanese patient, 12(9):130-132.

(WHO) World Health Organization (2012): WHO guidelines on the pharmacological treatment of persisting pain in children with medical illnesses. Accessed on 2 May 2017. Retrieved from: http://www, who. Int/patient safety/en/.

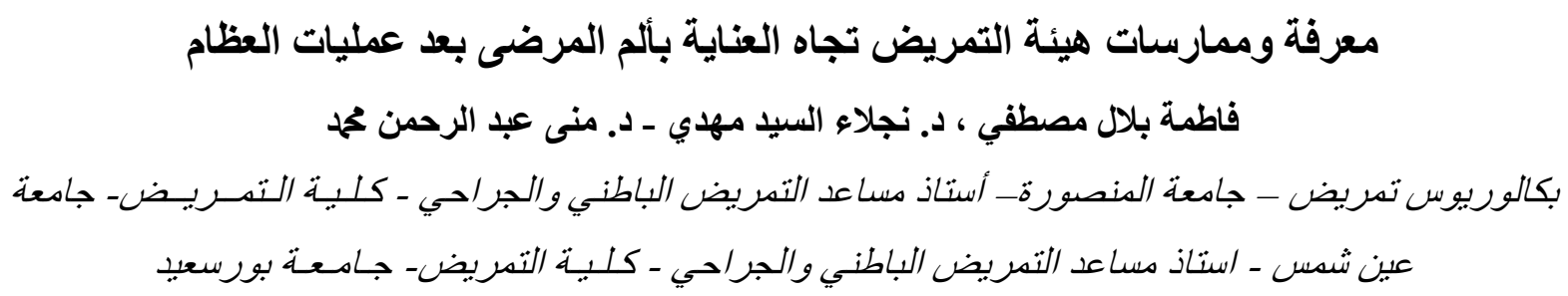

الخلفية: تعتبر إدارة الألم عنصراً حيوياً في الرعاية التمريضية اللاحقة للعمليات الجراحية. يعاني مرضى العظام بشكل خاص من آلام حادة بعد التدخل الجر احي ،فكان من الضروري استكثاف المعرفة و الممارسة السريرية للممرضات في عنابر العظام. هدف الدراسة: هدفت هذه الدراسة إلى تقييم معرفة وممارسات هيئة التمريض فيما يتعلق بإدارة الألم بعد العملية لمرضى العظام. التصميم:تم استخدام دراسة وصفية. مكان البحث: تم إجراء هذه الدراسة في قسم العظام في المستشفى الحكومي العام ومستشفى المبرة للتأمين الصحي بمدينة بورسعيد. العينة: عينة متاحة مناسبة من 50 ممرضة تقدم الرعاية التمريضية للمرضى في قسم تقويم العظام ، مستتفى حكومي عام ، 30 ممرضة من المستشفى الحكومي العام، و 20مرضة

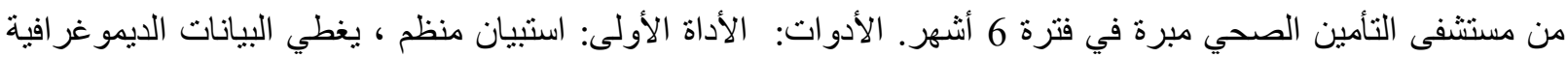

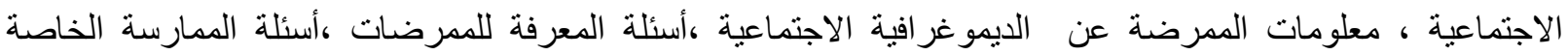
بالممرضات تجاه العناية بألم المرضى بعد عمليات العظام.الأداة الثاني: الأداة الثانية استمارة تقييم وملاحظة ممارسات المررضات .نتائج الدر اسة: وجد أن60٪ من الممرضات لايهن مستوى غير مُرضي من المعلومات تجاه علاج الألم ، 90٪ منهن كان لديهن مستوى غير مُرضِي من المهار ات لعلاج الألم. الخلاصة: ليست هنالك علاقة بشكل ثابت بين إجمالي المعرفة ، إجمالي الممارسة الكلية. التوصيات: هناك حاجة واضحة لتنفيذ برامج تعليمية وتدرييية لتحسين معلومات وممارسات الممرضين، تجاه العناية بألم المرضى بعد عمليات العظام. الكلمات المرشدة: العناية بالألم، دعلومات و مدارسات المدرضات، علاج ،عمليات العظام 
